\title{
Molecular characterization of ageratum enation virus and beta satellite associated with leaf curl disease of fenugreek in India
}

\author{
P Swarnalatha ${ }^{1}$, V Venkataravanappa ${ }^{1,2,{ }^{*}}$, C N Lakshminarayana Reddy ${ }^{3}$, M Sunil Kumar ${ }^{1}$, and M Krishna Reddy ${ }^{1}$ \\ ${ }^{1}$ Indian Institute of Horticultural Research (IIHR), Hessaraghatta Lake PO, Bangalore, Karnataka-560089, India \\ ${ }^{2}$ Central Horticultural Experiment Station (CHES), Chettalli Rd, Chetalli, Karnataka-571248, India \\ ${ }^{3}$ Department of Plant Pathology, College of Agriculture, University of Agricultural Sciences, GKVK, Bangalore, Karnataka-560065, India \\ ${ }^{*}$ Corresponding author: venkatrajani@gmail.com
}

SUBMITTED 23 September 2019 REVISED 26 October 2019 ACCEPTED 18 November 2019

\begin{abstract}
Six fenugreek (Trigonella foenum-graecum L.) plant samples showing leaf curl disease symptoms were collected from Pantnagar, Uttarakhand state of India. The disease was successfully transmitted by whitefly (Bemisia tabaci) to healthy seedlings of fenugreek. PCR using begomovirus-specific primers amplified an expected 1.2-kb product of virus genome, and its determined sequence suggested that the six infected fenugreek plant samples were associated with previously described monopartite begomovirus, ageratum enation virus (AEV) (nucleotide identities is more $98 \%$ among themselves). Therefore, one sample (BG199) was selected for full-length genome (DNA-A) and subviral (beta satellite) DNA amplification using rolling circle amplification method. Sequence Demarcation Tool (SDT) analysis of the complete genome of the isolate BG199 and beta satellite showed highest nucleotide (nt) identity of 93.7-98.7\% and 90.7-95.6\% with AEV and ageratum yellow leaf curl beta satellite (AYLCB), respectively. Further analysis of the recombinant origin of the genome (DNA-A) and beta satellite showed a major part of their genome was likely to be originated from the recombination of previously reported begomoviruses and beta satellites infecting different crops resulting in the evolution of a new recombinant virus. This is the first report of AEV, and AYLCB beta satellite components associated with leaf curl disease of fenugreek from India.
\end{abstract}

KEYWORDS ageratum enation virus; ageratum yellow leaf curl beta satellite; fenugreek; leaf curl disease

\section{Introduction}

Fenugreek (Trigonella foenum-graecum L.) belonging to the subfamily Papilionaceae under family Fabaceae is an annual legume crop native to South-Eastern Europe and Africa. The crop is now commercially cultivated in different parts of the world viz. India, Mediterranean region, China, Africa, Europe, and Australia, and North America. India is one of the major leading producers and exporters of fenugreek. The crop is being traditionally used as spice and vegetables for human consumption and forage for cattle. The seeds of fenugreek have a characteristic odor and flavor having a pleasantly bitter taste, and have important medicinal and nutraceutical properties. Extensive research on medicinal properties of fenugreek seeds revealed that its anti-diabetic, antinociceptive, hypocholesterolemic, anti-cancer and thyroxine-induced hyperglycemia properties. Because of the multi-use nature, fenugreek has the potential to expand into new areas, as well as an increase in the area where it was traditionally grown. Therefore, its reaction to biotic and abiotic factors that can limit its production deserves special at- tention. Fenugreek is affected by many fungal (Acharya et al. 2010; Ryley 1989; Zimmer 1984; Leppik 1959), bacterial (Petropoulos 2002), and viral diseases, which are most serious, destructive and widespread diseases and can cause considerable economic losses in different parts of the world. Among the various viruses, which hampered the production and cultivation of fenugreek are Turnip mosaic virus, Pea mosaic virus, Bean yellow mosaic virus, Wisconsin pea streak virus, Cucumber mosaic virus and Pea enation mosaic virus (Fischer and Lockhart 1976; Bhaskar and Summanwar 1982; Champawat and Singh 2007). The report of DNA viruses in India on fenugreek is very scanty. With this backdrop, the roving survey was conducted for the collection of fenugreek viral disease samples in and around Pantnagar in Uttarakhand, India, during 2012. During collection, it was observed that some of the fenugreek plants showed unusual severe leaf curl disease symptoms, which were typically the diseases caused by begomoviruses on other crops (Paul et al. 2009; Venkataravanappa et al. 2016). However, an exact causal agent cannot be identified based on the visual symptoms alone. Therefore, the current study was attempted to characterize the type of virus associated with the leaf curl dis- 
ease of fenugreek in India.

\section{Materials and Methods}

\subsection{Collection of disease samples}

The six fenugreek leaves samples showing the severe leaf curl disease symptoms along with non-symptomatic leaves samples were collected from farmer's fields in and around Pantnagar, Uttarakhand state of India (Figure 1). Both symptomatic and non-symptomatic tissues were used for analysis.

\subsection{Whitefly transmission}

The collection and maintenance of whiteflies (Bemisia tabaci, Asia 1) and transmission studies were done as described by Venkataravanappa et al. (2017). After inoculations, the fenugreek plants were sprayed with insecticide (Imidacloprid 200 SL) and maintained under insect-proof glasshouse for symptoms expression.

\subsection{DNA isolation and PCR confirmation of bego- movirus in fenugreek plants}

Total genomic DNA was extracted from six symptomatic and one non-symptomatic leaves samples of fenugreek by plants using the CTAB method (Doyle and Doyle 1990). The PCR using a begomovirus-specific primer pair 2395F/680R (Venkataravanappa et al. 2012) produced a product with the expected size $(1.2 \mathrm{~kb})$ from all six symptomatic fenugreek leaves samples, suggesting begomovirus(es) as the pathogen(s). One sample (BG199) was selected for full-length amplification of the begomovirus genome (DNA-A) by rolling circle amplification method using an Illustra TempliPhi 100 Amplification kit (Amersham Biosciences, Piscataway, NJ, USA) following the manufacturer's instructions. The RCA products were digested with different restriction endonucleases (EcoRI, XbaI, BamHI, and HindIII) to identify enzymes, which can give the yield of $2.8 \mathrm{~kb}$ DNA fragment. Among the different enzymes, BamHI gave the maximum length of $2.8 \mathrm{~kb}$ linear DNA fragments, which were cloned into the BamHI-linearized pUC19 plasmid as described by Venkataravanappa et al. (2016). The ligated products were transformed into a competent DH5 $\alpha$ strain of Escherichia coli. Colony PCR followed by restriction digestion with BamHI and ScaI was performed for the confirmation of recombinant clones. The confirmed clones were sequenced in both orientations.

The association of the betasatellite was analyzed by PCR using the betasatellite-specific primers beta01/beta02 (Briddon et al. 2002) as described previously for the detection of subgenomic components of the begomovirus in many crops.

\subsection{Sequence analysis}

Sequence similarity search of DNA-A component and betasatellite of fenugreek isolate (BG199) were performed by comparing the sequence to all the available sequences in the GenBank database using BlastN (Altschul et al. 1990) (Supplementary table 1a and 1b). Sequences showing the highest identity scores with the present Fenugreek isolate were aligned using the Muscle method implemented in Species Demarcation Tool (SDT) (Muhire et al. 2014) and percent pairwise identity of the identified sequences and the representative sequences were generated. A phylogenetic tree was generated using MEGA7 software (Kumar et al. 2016) using the neighbor-joining method with 1000 bootstrapped replications to estimate evolutionary distances between all pairs of sequences simultaneously. Recombination analysis was carried out using the Recombination detection program (RDP), GENECOV, BOOTSCAN, MAXCHI, CHIMAERA, SISCAN, 3SEQ which are integrated with RDP4 (Martin et al. 2015).

\section{Results and Discussion}

\subsection{Whitefly transmission and detection of the virus in fenugreek samples}

The causal agent(s) of fenugreek leaf curl disease was successfully transmitted by the whitefly, Bemisia tabaci, from naturally infected to healthy fenugreek plants (10/10) and developed identical leaf curl disease symptoms between 10-12 days post-inoculation. As there is a probability that field-collected plants may have contaminated by more than one virus, the repeated artificial transmission was carried out under controlled conditions to check whether typical symptoms were expressed or not. The transmission experiment was repeated thrice, and the symptoms remained the same after every case of transmission, excluding the possibility of mixed infection with whitefly non-transmissible agents. The same symptom expression after repeated transmission indicated the possible absence of mixed infection in the source material.
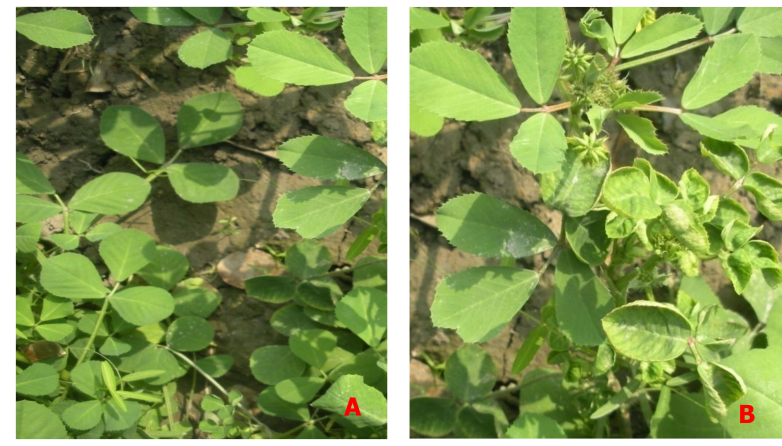

FIGURE 1 (A) Healthy fenugreek plant; (B) fenugreek plant showing a typically "severe upward leaf curl, enation, vein twisting, reduced in leaf size" symptoms under natural conditions.

The PCR using the begomovirus-specific primer pair 2395F/680R (Venkataravanappa et al. 2012) produced a product with the expected size $(1.2 \mathrm{~kb})$ from all six symptomatic fenugreek leaf samples, suggesting begomovirus(es) as the pathogen(s). Amplification with nucleic acid extracts yielded no product from healthy control plants. The resultant PCR amplified product $(1.2 \mathrm{~kb}$ 
fragment) was cloned and sequenced. The determined sequence of $1.2 \mathrm{~kb}$ fragment showed all six fenugreek isolates are closely related with more than $98 \%$ nucleotide identity, indicating the presence of a single species of begomovirus. Homology search analysis revealed that these sequences were most homologous (more than 98\% identity) to DNA-A of Ageratum enation virus (AEV). Therefore one sample (BG199) was selected for complete characterization. The complete genome of begomovirus from the fenugreek plant was amplified by rolling circle amplification (RCA), cloned and sequenced. Only DNA-A sequence and not DNA-B sequence was found for a $2.8 \mathrm{~kb}$ product, indicating the isolate under study is a monopartite begomovirus. Amplification of a $1.4 \mathrm{~kb}$ product by using beta01/beta02 (Briddon et al. 2002) suggested the presence of a subviral satellite DNA.

\subsection{Genome organization of DNA-A component of be- gomovirus}

The DNA-A component of fenugreek isolate (BG199) was determined to be $2753 \mathrm{nt}$ in length (under accession number JX436473) and showed it to be typical of the genome

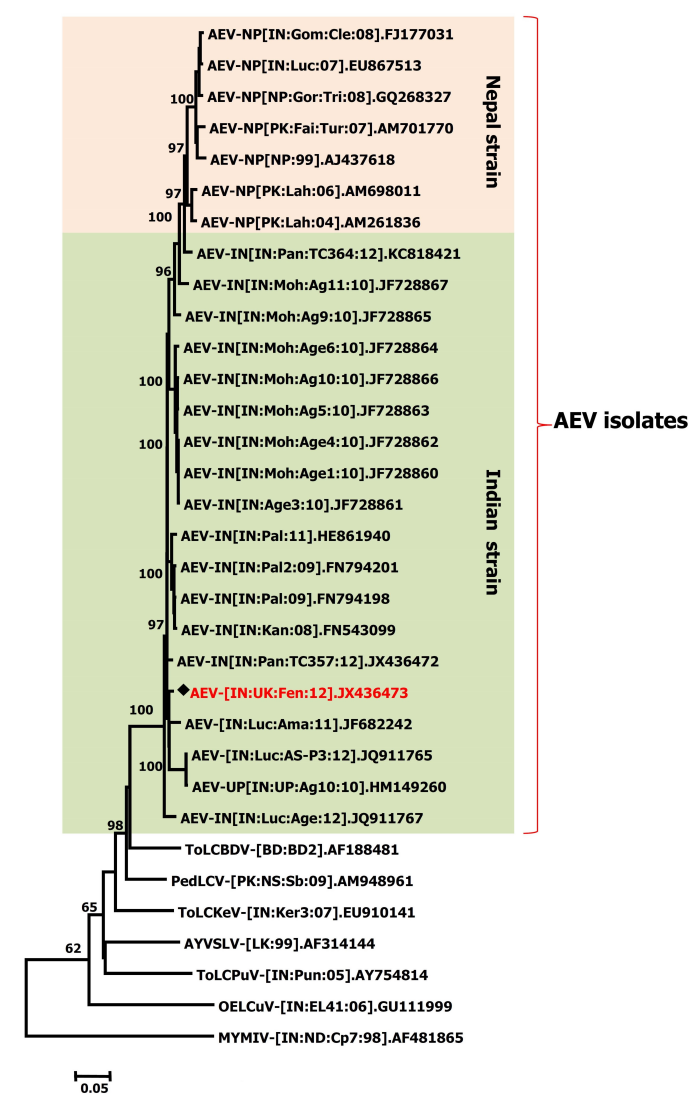

FIGURE 2 Phylogenetic trees constructed from aligned complete nucleotide sequence of begomovirus (AEV, JX436473) of fenugreek isolate with other begomoviruses using Neighbor-joining algorithm. Horizontal distances are proportional to sequence distances, vertical distances are arbitrary. The trees are unrooted. A bootstrap analysis with 1000 replicates was performed and the bootstrap percent values more than 50 are numbered along branches. The species name is denoted in Table 1. Black diamond indicates the isolate in the current study. organization of Old World monopartite begomoviruses with potential to encode six conserved ORFs: AV2 (movement protein), AV1 (coat protein) in sense orientation; and AC3 (replication enhancer protein), AC2 (transcriptional activator protein), AC1(replication-associated (Rep) protein) and AC4 (C4 protein) in antisense orientation with the capacity to encode proteins of predicted molecular mass of $11.05 \mathrm{kDa}$ or more. The SDT analysis of DNA A component of AEV infecting fenugreek and previously identified 25 additional sequences of AEV present in GenBank from India (18 sequences) and Nepal (7 sequences) showed the current isolate (BG199) has nt identity ranging from 93.7-98.7\% with India strains of AEV infecting different crops (Table 1) and 93.7-95.1\% nt identity with Nepal strains of AEV infecting different crops (Table 1). This confirms the 25 sequences as isolates of a distinct begomovirus species, which has previously been named AEV (Fauquet et al. 2003). A closer analysis of the AEV sequences revealed their segregation into three groups. The first group consists of AEV infecting fenugreek and India strains of AEV infecting different crops (JX436472, KC818421, JF682242, HE861940, JQ911767, JQ911765, HM149260, JF728860-JF728864, JF728866, FN794201, FN543099, and FN794198) sharing 91.8 to $100 \%$ nucleotide sequence identity among themselves (Data not showed). The AEV sequences in the second group consist of Nepal strains (FJ177031, GQ268327, EU867513, AM698011, AJ437618, AM701770, AM261836)] sharing $95.2 \%$ to $99.5 \%$ identity among them. Between the two groups, the identity levels vary between 93.7 to $95 \%$ (Data not shown). Thus AEV has geographical distinction and can be grouped into 'Nepal' and 'India' strains. The recently proposed criterion for distinguishing strains of begomoviruses (Brown et al. 2015) indicates that the fenugreek isolate in the present study is 'India' strain. The phylogenetic analysis of the complete nt sequence of fenugreek isolate (BG199) of AEV characterized in this study with selected begomovirus sequences available in the database revealed that, fenugreek isolate (BG199) is clustering with AEV isolates of the 'India' strain, and being distinct from isolates of the 'Nepal' strain (Figure 2). The third group of AEV sequences (JF728865 and JF728867) showing relatively high sequence identities to both India (group 1-94.8\% to 98.4\% nt identity) and Nepal (group 2- 94 to $98.0 \%$ nt identity) strain, making it difficult to assign them to a strain (Data not shown).

When individually encoded proteins of fenugreek isolate (BG199) were compared with other AEV isolates and related begomoviruses, encoded proteins were most similar to those of AEV (Table 1). The intergenic region (IR) of fenugreek isolate BG199 is 288 nt in length, and it is most similar to those of India strain isolates of AEV (87.7 to $99.3 \%$ nt Identity) (Table 1 ). The IR encompasses an absolutely conserved hairpin structure containing nonanucleotide sequence (TAATATTAC) that marks the origin of virion-strand DNA replication and two repeated sequences known as "iterons" were detected adjacent to the stem-loop region in isolate BG199 that are recognition se- 
TABLE 1 Pairwise percent of nucleotide identities between the genomic components and amino acid sequence identities of encoded genes from the AEV- Fenugreek (BG199) with the components and genes of selected other begomoviruses available in the databases.

\begin{tabular}{|c|c|c|c|c|c|c|c|c|c|c|}
\hline \multirow{2}{*}{ Begomoviruses* } & \multirow{2}{*}{ Crop } & \multirow{2}{*}{ Accession numbers } & \multirow{2}{*}{ Genome } & \multirow{2}{*}{ IR } & \multicolumn{6}{|c|}{ Gene (percentage amino acid sequence identity) } \\
\hline & & & & & V2 & $\mathrm{CP}(\mathrm{V} 1)$ & $\operatorname{Rep}(\mathrm{C} 1)$ & TrAP (C2) & REn (C3) & $\mathrm{C} 4$ \\
\hline AEV-IN & Tomato & $J X 436472$ & $\underline{98.7}$ & 98.9 & 97.4 & $\underline{99.7}$ & 97.5 & 95.5 & 97.7 & 98.8 \\
\hline AEV-IN & Soybean & HE861940 & 98.2 & 97.9 & 96.6 & 99.2 & 97.2 & $\underline{98.5}$ & 98.5 & 96.4 \\
\hline AEV-IN & Amaranthus cruentus & $J F 682242$ & 98 & 97.9 & $\underline{98.3}$ & 98.8 & 98.3 & 94.7 & 90.2 & 97.6 \\
\hline AEV-IN & $\begin{array}{l}\text { Crassocephalum } \\
\text { crepidioides }\end{array}$ & FN794201 & 98 & 98.2 & 96.6 & 99.6 & 96.9 & 93.2 & 97 & $\underline{100}$ \\
\hline AEV-IN & Ageratum sp. & FN794198 & 97.9 & 97.9 & 95.7 & 99.6 & 97.2 & 93.2 & 97 & 98.8 \\
\hline AEV-IN & Zinnia sp. & FN543099 & 97.8 & 97.5 & 96.6 & 99.6 & 96.3 & 93.2 & 97 & 98.8 \\
\hline AEV-IN & Ageratum sp. & JQ911767 & 97.5 & 99.3 & 97.4 & 99.6 & 96.1 & 91 & 88.8 & 98.8 \\
\hline AEV-IN & Ageratum & JF728866 & 97.5 & 97.5 & 94.9 & 99.6 & 97.7 & 89.5 & 95.5 & $\underline{100}$ \\
\hline AEV-IN & Ageratum & JF728863 & 97.5 & 97.5 & 94.9 & 99.6 & 97.7 & 89.5 & 95.5 & $\underline{100}$ \\
\hline AEV-IN & Ageratum & JF728862 & 97.4 & 97.1 & 94.9 & 99.6 & 97.7 & 89.5 & 95.5 & $\underline{100}$ \\
\hline AEV-IN & Ageratum & $J F 728860$ & 97.4 & 97.1 & 94.9 & 99.6 & 97.7 & 89.5 & 95.5 & $\underline{100}$ \\
\hline AEV-IN & Ageratum & JF728861 & 97.4 & 97.1 & 94.9 & 99.6 & 97.5 & 89.5 & 95.5 & $\underline{100}$ \\
\hline AEV-IN & Ageratum & JF728864 & 97.3 & 97.5 & 94.9 & 99.6 & 96.9 & 89.5 & 95.5 & $\underline{100}$ \\
\hline AEV-IN & Papaver somniferum & HM149260 & 97.1 & 99.2 & 94.9 & 93 & 98.5 & 98.4 & 97.7 & 98.8 \\
\hline AEV-IN & Papaver somniferum & JQ911765 & 96.8 & 99.2 & 94.9 & 96 & $\underline{98.6}$ & 98.4 & 97.7 & 98.8 \\
\hline AEV-IN & Carrot & JF728865 & 96.7 & 97.2 & 94.9 & 97.2 & 96.9 & 97 & 99.1 & 90.5 \\
\hline AEV-IN & Carrot & JF728867 & 96.2 & 97.2 & 94.9 & 97.6 & 93.6 & 97 & $\underline{99.2}$ & 85.8 \\
\hline AEV-IN & Tomato & KC818421 & 96.1 & 87.7 & 97.4 & 98.8 & 93.6 & 94 & 97 & 85.8 \\
\hline AEV-NP & Sonchus oleraceus & AM261836 & 95.1 & 85.8 & 94.9 & 97.2 & 93.6 & 91.6 & 98.5 & 85.8 \\
\hline AEV-NP & Ageratum & AM698011 & 95 & 85.7 & 94.9 & 99.2 & 93 & 95.5 & 97.7 & 85.8 \\
\hline AEV-NP & Cleome gynandra & FJ177031 & 94.6 & 79.8 & 94.9 & 99.6 & 92.5 & 94.7 & 90.2 & 87 \\
\hline AEV-NP & Amaranthus cruentus & EU867513 & 94.4 & 79.8 & 94 & 99.2 & 92.5 & 94.7 & 90.2 & 87 \\
\hline AEV-NP & Trichosanthes dioica & GQ268327 & 94.3 & 79.8 & 95.7 & 99.2 & 92.5 & 94.7 & 91 & 83.5 \\
\hline AEV-NP & Brassica rapa & AM701770 & 93.8 & 82.7 & 93.2 & 99.2 & 92.7 & 93.2 & 92.5 & 82.3 \\
\hline AEV-NP & Ageratum & AJ437618 & 93.7 & 82.3 & 94 & 98.8 & 93.3 & 91 & 90.2 & 83.5 \\
\hline PedLCV & Soybean & AM948961 & 88.4 & 82.6 & 95.7 & 98 & 87.2 & 85.8 & 87.3 & 60.2 \\
\hline ToLCBDV & Tomato & AF188481 & 87.6 & 84 & 95.7 & 99.2 & 83.6 & 82.8 & 87.3 & 48.4 \\
\hline ToLCKeV & Tomato & EU910141 & 85 & 75.1 & 91.5 & 95.7 & 82.8 & 88 & 86.5 & 62.2 \\
\hline AYVSLV & - & AF314144 & 81.6 & 78 & 77.1 & 92.5 & 79.7 & 76.8 & 82.8 & 43.2 \\
\hline ToLCPuV & Tomato & AY754814 & 80.1 & 71.3 & 69.4 & 90.6 & 79.2 & 80.5 & 79.1 & 49.4 \\
\hline OELCuV & Okra & GU111999 & 75.5 & 68.3 & 63.6 & 77.3 & 83.1 & 57.3 & 67.1 & 56 \\
\hline MYMIV & Mungbean & AF481865 & 68.6 & 66.3 & 39.4 & 73.9 & 67.4 & 47.7 & 39.5 & 33.3 \\
\hline
\end{tabular}

${ }^{*}$ The species are indicated as Ageratum enation virus (AEV), Pedilanthus leaf curl virus (PedLCV), Tomato leaf curl Bangladesh virus (ToLCBDV), Tomato leaf curl Kerala virus (ToLCKeV), Ageratum yellow vein Sri Lanka virus (AYVSLV), Tomato leaf curl Pune virus (ToLCPuV), Okra enation leaf curl virus (OELCuV), Mungbean yellow mosaic India virus (MYMIV). For each column the highest value is underlined.

quences for binding of the Rep protein (Argüello-Astorga and Ruiz-Medrano 2001; Hanley-Bowdoin et al. 1999). The BG199's iteron and corresponding iteron related domain (IRD) of Rep were GTACT and FQIY, respectively. These replication related sequences are identical to those of another India strain AEV-IN[IN:Kan:08] (FN543099), but are interestingly distinct from those of Nepal strains (GGT/AGT and LKIN, respectively) (Tahir et al. 2015).

\subsection{Genome organization of betasatellite and se- quence affinities to other betasatellites}

The complete nucleotide sequence of betasatellite isolated from fenugreek (BG199) was determined to be $1359 \mathrm{nt}$ in length, which is available in the NCBI database (under accession number KX108998). The betasatellite molecule under study showed several characteristic features in common with other betasatellite homologs reported from other crops, namely a conserved nonanucleotide situated in the stem-loop region, a highly conserved SCR, a conserved $\beta C 1 \mathrm{ORF}$, and an extensive A-rich region (Briddon et al. 2003). The conserved satellite region is approximately 142 nt and contains at its 3' end a predicted hairpin structure having a loop with the sequence TAATATTAC similar to the origin of replication of DNA-A.

The betasatellite characterized as part of this study shared nt identity ranged from 93.1-96.4\% with differ- 
TABLE 2 Percentages of nucleotide or amino acid sequence identities between betasatellite of Fenugreek and betasatellites of other begomoviruses.

\begin{tabular}{|c|c|c|c|c|c|c|}
\hline Betasatellites & Crop & Accession numbers & Nucleotide $^{a}$ & ORF $\beta C^{b}$ & A-rich ${ }^{a}$ & $\mathrm{SCR}^{\mathrm{a}}$ \\
\hline AYLCB & Carrot & JF728869 & $\underline{96.4}$ & $\underline{94.2}$ & 98.2 & 98.7 \\
\hline AYLCB & Ageratum & JF728868 & 96.3 & 94.2 & 98.5 & 98.6 \\
\hline AYLCB & Wheat & КС305085 & 96.1 & 94.2 & 98.2 & 97.9 \\
\hline AYLCB & Wheat & КС305084 & 96 & 94.2 & $\underline{98.6}$ & 97.9 \\
\hline AYLCB & Solanum nigrum & KJ028213 & 95.9 & 94.2 & $\underline{98.6}$ & 97.9 \\
\hline AYLCB & Ageratum & AM698010 & 94 & 92.7 & 93.7 & 97.8 \\
\hline AYLCB & Calotropis & KU376492 & 93.5 & 86.9 & 98.2 & 98.6 \\
\hline AYLCB & Calendula & KR922821 & 93.1 & 92 & 91.2 & 95.8 \\
\hline AYLCB & Calendula & KR922823 & 93.1 & 92 & 90.9 & 95.8 \\
\hline ChLCB & Chilli & AM279668 & 81.7 & 76.6 & 74.7 & 87 \\
\hline CLCuB & Cotton & GU440581 & 68.1 & 76.2 & 63.8 & 66.3 \\
\hline CLCuMuB & Hibiscus & FJ159274 & 61 & 58.8 & 63.9 & 53.6 \\
\hline CroYVMB & Crotalaria & GQ183865 & 76.2 & 61 & 68.5 & 63.5 \\
\hline PaLCuB & Papaya & EU126826 & 68.2 & 75 & 62.8 & 55.5 \\
\hline RaLCB & Chilli & JN663873 & 76.9 & 66.1 & 81.5 & 91.4 \\
\hline TbCSB & Tobacco & AJ421485 & 69.5 & 66.1 & 71.2 & 68.8 \\
\hline ToLCJoB & Chilli & JN663862 & 78.2 & 63.4 & 74.8 & 88 \\
\hline ToLCPnB & Tobacco & HQ180394 & 78.4 & 72 & 73.9 & 94.2 \\
\hline ToLCBDB & Okra & GU732208 & 80.5 & 59.5 & 73.5 & 88.5 \\
\hline ToLCuB & Papaya & HM143907 & 79.7 & 77.9 & 79.6 & 84 \\
\hline ToLCBDB & Tomato & AJ542489 & 80.7 & 80.5 & 75.3 & 88.4 \\
\hline
\end{tabular}

a Nucleotide sequence identity.

${ }^{b}$ Amino acid sequence identity.

The species are indicated as Ageratum yellow leaf curl betasatellite (AYLCB), Chili leaf curl betasatellite (ChLCB), Cotton leaf curl betasatellite (CLCuB), Cotton leaf curl Multan betasatellite (CLCuMuB), Croton yellow vein mosaic betasatellite (CroYVMB), Papya leaf curl betasatellite (PaLCuB), Radish leaf curl betasatellite (RaLCB), Tobacco curly shoot betasatellite (TbCSB), Tomato leaf curl Joydebpur betasatellite (ToLCJoB), Tomato leaf curl Patna betasatellite (ToLCPnB), Tomato leaf curl betasatellite (ToLCuB), Tomato leaf curl Bangladesh betasatellite (ToLCBDB). For the NSI column the highest value is underlined.

ent isolates of Ageratum yellow leaf curl betasatellite (AYLCB) from India, Pakistan (Table 2). Based on the proposed species demarcation threshold of $78 \%$ for betasatellites (Briddon et al. 2008), the results suggested that betasatellite identified here is an isolate of AYLCB. A phylogenetic analysis based upon an alignment of the complete sequence of betasatellite isolated from fenugreek with selected betasatellites available in the databases showed that the betasatellite isolated from fenugreek is closely clustering with the previously reported isolates of AYLCB (Figure 3).

\subsection{Neighbor-net and Recombination analysis}

To detect possible evidence of recombination in the viral genome of fenugreek isolate (BG199), the RDP analysis was performed along with begomoviruses $[\mathrm{ToLCKeV}$ (EU910141), MYMIV (AF481865), AEV (EU867513, HM149260 and FN543099), ToLCKeV (EU910141) and ToLCPuV (AY754814)] and betasatellites [AYLCuB (AM698010 and KU376492), CroYVMB, (JQ354987) and (TbCSB, AJ457822)]. The RDP analysis revealed that the fenugreek isolate (BG199) is recombinant with known species. The analysis indicated both Intra and interspecific recombination in DNA-A and betasatellites (Table 3). A recombination fragment of 544 nucleotides was detected in the DNA-A component of BG199 with major and minor parents resembling Tomato leaf curl Kerala virus (ToLCKeV, EU910141) and Mungbean yellow mosaic India virus (MYMIV, AF481865), respectively. The breakpoints were determined at nucleotides 580 and 1124 , with an average probability value of $2.559 \times 10^{-2}$. Another recombination fragment of 1965 nucleotides was detected with major and minor parents resembling variants of Ageratum enation virus (AEV)(EU867513 and HM149260). The breakpoints were predicted at nucleotides 399 and 2364, with an average probability value of $9.197 \times 10^{-15}$. A recombination fragment of $718 \mathrm{nu}-$ cleotides was detected with major and minor parents resembling variants of Ageratum enation virus (FN543099 and HM149260). Similarly, the breakpoints were determined at nucleotides 1293 and 2011, with an average probability value of $6.472 \times 10^{-94}$. Another recombination fragment of 144 nucleotides was detected with major and minor parents resembling Tomato leaf curl Kerala virus 
TABLE 3 Breakpoint analysis of AEV- fenugreek and their putative parental sequences.

\begin{tabular}{|c|c|c|c|c|c|c|c|c|c|}
\hline \multirow[t]{2}{*}{ DNA-A } & \multirow{2}{*}{$\begin{array}{l}\text { Break point } \\
\text { begin-end }^{\mathrm{a}}\end{array}$} & \multirow{2}{*}{ Major Parent } & \multirow[t]{2}{*}{ Minor parent } & \multicolumn{6}{|c|}{ P-Values } \\
\hline & & & & RDP & GENECOV & Max Chi & Chimera & Si Scan & 3Seq \\
\hline \multirow[t]{4}{*}{ AEV } & $\begin{array}{l}580-1124 \\
(A \vee 2, C P)\end{array}$ & $\begin{array}{l}\text { ToLCKeV- } \\
\text { [IN:Ker3:07] } \\
\text {.EU910141 }\end{array}$ & $\begin{array}{l}\text { MYMIV- } \\
\text { [IN:ND:Cp7:98] } \\
\text {.AF481865 }\end{array}$ & NS & NS & $1.848^{*} 10^{-6}$ & $1.308 * 10^{-2}$ & $4.099 * 10^{-20}$ & NS \\
\hline & $\begin{array}{l}\text { 399-2364 } \\
\text { (TrAP, REn, } \\
\text { REP) }\end{array}$ & $\begin{array}{l}\text { AEV- } \\
\text { NP[IN:Luc:07] } \\
\text {.EU867513 }\end{array}$ & $\begin{array}{l}\text { AEV- } \\
\text { [IN:UP:Ag10:10] } \\
. \text { HM149260 }\end{array}$ & $3.877^{*} 10^{-8}$ & $3.93 * 10^{-21}$ & $2.09 * 10^{-11}$ & $1.41 * 10^{-12}$ & $1.967 * 10^{-10}$ & $1.92^{*} 10^{-5}$ \\
\hline & $\begin{array}{l}\text { 1293-2011 } \\
\text { (TrAP, REn, } \\
\text { REP) }\end{array}$ & $\begin{array}{l}\text { AEV- } \\
\text { IN[IN:Kan:08] } \\
\text {.FN543099 }\end{array}$ & $\begin{array}{l}\text { AEV- } \\
\text { [IN:UP:Ag10:10] } \\
\text {.HM149260 }\end{array}$ & NS & NS & NS & NS & $5.19^{*} 10^{-5}$ & $4.104^{*} 10^{-2}$ \\
\hline & $\begin{array}{l}2081-2225 \\
\text { (REP, AC4) }\end{array}$ & $\begin{array}{l}\text { ToLCKeV- } \\
\text { [IN:Ker3:07] } \\
\text {.EU910141 }\end{array}$ & $\begin{array}{l}\text { ToLCPuV- } \\
\text { [IN:Pun:05] } \\
\text {.AY754814 }\end{array}$ & $1.78 * 10^{-3}$ & NS & $6.99 * 10^{-3}$ & $6.45^{*} 10^{-3}$ & $4.005^{*} 10^{-10}$ & $3.06^{*} 10^{-2}$ \\
\hline \multicolumn{10}{|c|}{ Betasatellites } \\
\hline \multirow[t]{2}{*}{ AYLCB } & $98-509(\beta C 1)$ & $\begin{array}{l}\text { AYLCB } \\
\text { [PK:Lah:ae:06] } \\
\text {.AM698010 }\end{array}$ & $\begin{array}{l}\text { AYLCuB- } \\
\text { [IN:HR:CB1:15] } \\
. \text { KU376492 }\end{array}$ & NS & NS & NS & NS & $2.11 * 10^{-6}$ & $3.92 * 10^{-2}$ \\
\hline & $\begin{array}{l}892-1086 \\
\text { (SCR, A-rich) }\end{array}$ & $\begin{array}{l}\text { CroYVMB- } \\
\text { [IN:Bang:12] } \\
\text {.JQ354987 }\end{array}$ & $\begin{array}{l}\text { TbCSB- } \\
\text { [CN:Yn115:02] } \\
\text { AJ457822 }\end{array}$ & $9.053^{*} 10^{-5}$ & $2.23 * 10^{-13}$ & $3.185 * 10^{-6}$ & $1.131 * 10^{4}$ & $1.622 * 10^{-14}$ & $3.614^{*} 10^{-4}$ \\
\hline
\end{tabular}

NS- Recombination Non-significance

a The text in the parenthesis of this column indicates ORF's in which breakpoints were identified

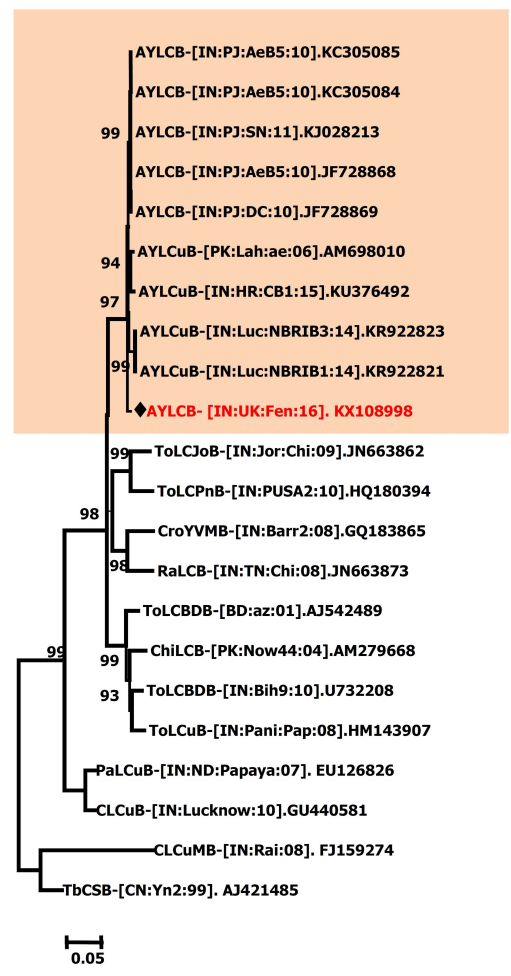

FIGURE 3 Phylogenetic trees constructed from aligned complete nucleotide sequences of betasatellite (KX108998) of fenugreek isolate with other betasatellites retrieved from the database using Neighbor-joining algorithm. Horizontal distances are proportional to sequence distances, vertical distances are arbitrary. The trees are unrooted. A bootstrap analysis with 1000 replicates was performed and the bootstrap percent values more than 50 are numbered along branches. The betasatellite name is denoted in Table 2. Black diamond indicates the isolate in the current study.
(ToLCKeV, EU910141) and Tomato leaf curl Pune virus (ToLCPuV, AY754814). The breakpoints were predicted at nucleotides 2081 and 2225, with an average probability value of $5.83 \times 10^{-4}$ (Table 3 ).

Similarly, a recombination fragment of $411 \mathrm{nu}-$ cleotides was detected in betasatellite of fenugreek isolate (BG199) with major and minor parents resembling Ageratum yellow leaf curl betasatellite (AYLCuB, AM698010, and KU376492). The breakpoints were determined at nucleotides 98 and 509, with an average probability value of $4.041 \times 10^{-7}$. Another recombination fragment of 194 nucleotides was detected with major and minor parents resembling Croton yellow vein mosaic betasatellite (CroYVMB, JQ354987) and Tobacco curly shoot betasatellite (TbCSB, AJ457822). The breakpoints were predicted at nucleotides 892 and 1086, with an average probability value of $9.41 \times 10^{-13}$ (Table 3 ).

\subsection{Discussion}

Begomoviruses cause huge economic losses to food and fiber crops worldwide, mainly in tropical and subtropical regions of the world (Varma and Malathi 2003). The begomoviruses are transmitted by the whitefly vector, Bemisia tabaci species complex, on cultivated and weed crops and causing economically important diseases on various crops in different parts of the world. Among the different weed infecting begomoviruses, Ageratum enation virus (AEV) has wide host range covering both cultivated plants and weeds; families including AEV hosts are Asteraceae ( $A$. conyzoides, Z. elegans, C. crepidioides, Tagetes patula and S. oleraceous), Amaranthaceae (A. cruentus), Apiaceae (carrot), Brassicaceae (turnip), Cucurbitaceae ( $T$. 
dioica), and Cleomaceae (C. gynandra).This indicates that $\mathrm{AEV}$ is predominantly a weed infecting begomovirus, although it apparently has the capacity to occasionally infect crop species viz. tomato (Swarnalatha et al. 2013), carrot (Kumar et al. 2013), Trichosanthes dioica (Raj et al. 2011), Cleome gynandra (Raj et al. 2010), Zinnia and Ageratum (Kumar et al. 2010, 2011) in India. In this report, we identified a new isolate of Ageratum enation virus (AEV) and Ageratum yellow leaf curl betasatellite (AYLCB) associated with the leaf curl disease of fenugreek. First, the agent was repeatedly transmitted by whitefly and produced identical symptoms, excluding the possibility of mixed infection with whitefly non-transmissible agents. Second, begomovirus-specific primers were used to amplify a part begomovirus genome (1.2 kb), indicating the involvement of begomovirus(es). Third, sequencing of the RCA amplified products (six clones) resulted in only one sequence most similar to AEV, suggesting an association of only $\mathrm{AEV}$, and excluding the possibility of mixed infection with other begomoviruses. Fourth, obtaining the whole DNA-A sequence with more than $91 \%$ identity to that of $\mathrm{AEV}$, finally suggesting it as an isolate of AEV associated with leaf curl disease of Fenugreek.

Recombination is a major driving force in the evolution of Geminiviruses (Seal et al. 2006a,b). The fenugreek isolate (BG199) in present study had both intra and interspecific recombination suggesting most of the DNA-A (AEV) and its betasatellite (AYLCB) sequence fragments might have descended from begomoviruses (ToLCKeV, MYMIV, AEV, and ToLCPuV) and betasatellites (AYLCuB, CroYVMB and TbCSB) reported earlier resulting in evolution of new strain similar to its ancestors.

\section{Conclusions}

Fenugreek is one of the traditionally used spices, vegetables, and forage crops used for human and cattle consumption. The seeds have great medicinal value and are rich in oils, alkaloids, vitamins, and minerals used in Ayurvedic medicines. Therefore, the occurrence of AEV on fenugreek (Trigonella foenum-graecum L.) is a serious concern for growers in the traditional growing regions. Therefore the future study in the identification of resistance sources in fenugreek (Trigonella foenum-graecum L.) may effectively manage the epidemic caused by this deadly virus.

\section{Acknowledgments}

The research was supported by a project on the "Consortium platform on Vaccines and diagnostics" Indian Council of Agricultural Research, Government of India, New Delhi, India.

\section{Authors' contributions}

PS, VV, and CNLR designed the study. MSK collected the data. CNLR performed acquisition dan analyzed the data.
PS, VV, and MKR wrote and revised the manuscript. All authors read and approved the final version of the article.

\section{Competing interests}

The authors declare no competing interest.

\section{References}

Acharya SN, Thomas JE, Prasad R, K BS. 2010. Diseases of fenugreek (Trigonella foenum-graecum L.) and control measures with special emphasis on fungal diseases, chapter 19, pages 245-262. Wallingford: CABI. doi:10.1079/9781845936037.0245.

Altschul SF, Gish W, Miller W, Myers EW, Lipman DJ. 1990. Basic local alignment search tool. J Mol Biol 215(3):403-410. doi:10.1016/S00222836(05)80360-2.

Argüello-Astorga GR, Ruiz-Medrano R. 2001. An iteronrelated domain is associated to Motif 1 in the replication proteins of geminiviruses: identification of potential interacting amino acid-base pairs by a comparative approach. Arch Virol 146(8):1465-1485. doi:10.1007/s007050170072.

Bhaskar RBL, Summanwar AS. 1982. Physical properties and host range of methi mosaic wilt virus [fenugreek: Trigonella foenum-graecum L.]. Indian Phytopathol 35:688-689.

Briddon RW, Brown JK, Moriones E, Stanley J, Zerbini M, Zhou X, Fauquet CM. 2008. Recommendations for the classification and nomenclature of the DNA- $\beta$ satellites of begomoviruses. Arch Virol 153(4):763781. doi:10.1007/s00705-007-0013-6.

Briddon RW, Bull SE, Amin I, Idris AM, Mansoor S, Bedford ID, Dhawan P, Rishi N, Siwatch SS, AbdelSalam AM, et al. 2003. Diversity of DNA $\beta$, a satellite molecule associated with some monopartite begomoviruses. Virology 312(1):106-121. doi:10.1016/S0042-6822(03)00200-9.

Briddon RW, Bull SE, Mansoor S, Amin I, Markham PG. 2002. Universal primers for the PCR-mediated amplification of DNA $\beta$. Mol Biotechnol 20(3):315-318. doi:10.1385/MB:20:3:315.

Brown JK, Zerbini FM, Navas-Castillo J, Moriones E, Ramos-Sobrinho R, Silva JCF, Fiallo-Olivé E, Briddon RW, Hernández-Zepeda C, Idris A, et al. 2015. Revision of Begomovirus taxonomy based on pairwise sequence comparisons. Arch Virol 160(6):15931619. doi:10.1007/s00705-015-2398-y.

Champawat RS, Singh V. 2007. Seed Spices, pages 197232. Jodhpur: Scientific Publishers (India).

Doyle JJ, Doyle JL. 1990. Isolation of plant DNA from fresh tissue. Focus 12(13):39-40.

Fauquet CM, Bisaro DM, Briddon RW, Brown JK, Harrison BD, Rybicki EP, Stenger DC, Stanley J. 2003. Virology division news: revision of taxonomic criteria for species demarcation in the family Geminiviridae, 
and an updated list of begomovirus species. Arch Virol 148(2):405-421. doi:10.1007/s00705-002-09575.

Fischer HU, Lockhart BEL. 1976. A Moroccan isolate of turnip mosaic virus infectious to garden pea and other legumes. Plant Dis Rep 60(5):398-401.

Hanley-Bowdoin L, Settlage SB, Orozco BM, Nagar S, Robertson D. 1999. Geminiviruses: models for plant DNA replication, transcription, and cell cycle regulation. Crit Rev Plant Sci 18(1):71-106. doi:10.1080/07352689991309162.

Kumar J, Gunapati S, Singh SP, Gadre R, Sharma NC, Tuli R. 2013. Molecular characterization and pathogenicity of a carrot (Daucus carota) infecting begomovirus and associated betasatellite from India. Virus Res 178(2):478-485. doi:10.1016/j.virusres. 2013.10.010.

Kumar S, Stecher G, Tamura K. 2016. MEGA7: molecular evolutionary genetics analysis version 7.0 for bigger datasets. Mol Biol Evol 33(7):1870-1874. doi:10.1093/molbev/msw054.

Kumar Y, Bhardwaj P, Hallan V, Zaidi AA. 2010. Detection and characterization of Ageratum enation virus and a nanovirus-like satellite DNA1 from zinnia causing leaf curl symptoms in India. J Gen Plant Pathol 76(6):395-398. doi:10.1007/s10327-010-0270-1.

Kumar Y, Hallan V, Zaidi A. 2011. First report of Ageratum enation virus infecting Crassocephalum crepidioides (Benth.) S. Moore and Ageratum conyzoides L. in India. J Gen Plant Pathol 77(3):214-216. doi:10.1007/s10327-011-0308-z.

Leppik EE. 1959. World distribution of Cercospora traversiana. FAO Plant Prot Bull 8:19-21.

Martin DP, Murrell B, Golden M, Khoosal A, Muhire B. 2015. RDP4: Detection and analysis of recombination patterns in virus genomes. Virus Evol 1(1):1-5. doi:10.1093/ve/vev003.

Muhire BM, Varsani A, Martin DP. 2014. SDT: a virus classification tool based on pairwise sequence alignment and identity calculation. PLoS One 9(9):e108277. doi:10.1371/journal.pone.0108277.

Paul S, Ghosh R, Das S, Palit P, Acharyya S, Das A, Mir J, Chaudhuri S, Ghosh S, Roy A, et al. 2009. First report of Tomato leaf curl Joydebpur virus and associated betasatellite in kenaf (Hibiscus cannabinus) plants showing leaf curl symptoms from southern India. Plant Pathol 58(2). doi:10.1111/j.13653059.2008.01929.x.

Petropoulos GA. 2002. Fenugreek: The Genus Trigonella. London: CRC Press, 1st edition.

Raj SK, Snehi SK, Khan MS, Tiwari AK, Rao GP. 2010. Detection of Ageratum enation virus from cat's whiskers (Cleome gynandra L.) with leaf curl symptoms in India. J Gen Plant Pathol 76(4):292-294. doi:10.1007/s10327-010-0243-4.

Raj SK, Snehi SK, Khan MS, Tiwari AK, Rao GP. 2011. Molecular identification of an Ageratum enation virus isolate associated with mosaic disease of pointed gourd (Trichosanthes dioica) in India. Phytoparasitica 39(5):497-502. doi:10.1007/s12600-011-0182-4.

Ryley MJ. 1989. Cercospora traversiana on fenugreek (Trigonella foenum-graecum) in Queensland. Australas Plant Pathol 18(3):60-63. doi:10.1071/APP9890060.

Seal SE, Jeger MJ, vandenBosch F. 2006a. Begomovirus evolution and disease management. Adv Virus Res 67:297-316. doi:10.1016/S0065-3527(06)67008-5.

Seal SE, vandenBosch F, Jeger MJ. 2006b. Factors influencing begomovirus evolution and their increasing global significance: implications for sustainable control. Crit Rev Plant Sci 25(1):23-46. doi:10.1080/07352680500365257.

Swarnalatha P, Kanakala S, Manasa M, Jalali S, Reddy MK. 2013. Molecular characterization of tobacco curly shoot virus infecting tomato (Solanum lycopersicum L.) in India. Pest Manag Hort Ecosyst 19(1):73-84.

Tahir M, Amin I, Haider M, Mansoor S, Briddon R. 2015. Ageratum enation virus-A Begomovirus of Weeds with the Potential to Infect Crops. Viruses 7(2):647665. doi:10.3390/v7020647.

Varma A, Malathi VG. 2003. Emerging geminivirus problems: a serious threat to crop production. Ann Appl Biol 142(2):145-164. doi:10.1111/j.17447348.2003.tb00240.x.

Venkataravanappa V, Kodandaram MH, Reddy CNL, Shankarappa KS, Reddy MK. 2017. Comparative transmission of Bhendi yellow vein mosaic virus by two cryptic species of the whitefly, Bemisia tabaci (Hemiptera: Aleyrodidae). 3 Biotech 7(5):331. doi:10.1007/s13205-017-0970-8.

Venkataravanappa V, Reddy CNL, Jalali S, Reddy MK. 2012. Molecular characterization of distinct bipartite begomovirus infecting bhendi (Abelmoschus esculentus L.) in India. Virus Genes 44(3):522-535. doi:10.1007/s11262-012-0732-y.

Venkataravanappa V, Swarnalatha P, Reddy CNL, Chauhan N, Reddy MK. 2016. Association of recombinant Chilli leaf curl virus with enation leaf curl disease of tomato: a new host for chilli begomovirus in India. Phytoparasitica 44(2):213-223. doi:10.1007/s12600-016-0510-9.

Zimmer RC. 1984. Cercospora leaf spot and powdery mildew of fenugreek, a potential new crop in Canada. Can Plant Dis Surv 64(2):33-35. 